\title{
The manipulation of the advertising discourse: rhetoric and stylistic aspects
}

\section{La manipulación del discurso publicitario: aspectos retóricos y estilísticos}

\section{Sergey Mokshin}

Senior lecturer of the department of commerce and advertising, Siberian University of Consumer cooperation, Novosibirsk.

ORCID: https://orcid.org/0000-0002-8242-2439

Received 02-12-20 Revised 04-25-20

\section{*Correspondence}

Email: ivannovadremova29@gmail.com
Accepted 01-13-21 On line 01-22-21

Cite as:

Mokshin, S. (2021). The manipulation of the advertising discourse: rhetoric and stylistic aspects. Propósitos y Representaciones, 9 (SPE1), e916. Doi: http://dx.doi.org/10.20511/pyr2021.v9nSPE1.916

(C) Universidad San Ignacio de Loyola, Vicerrectorado de Investigación, 2021. 


\section{Summary}

The article presents communicative, stylistic and rhetoric facets of the advertising discourse. The purpose of the study is to give consideration to communicative (rhetoric and stylistic) means of the advertising discourse in the role of suggestive practices acting as the mind manipulation. The main objective of such means is to sell goods via mass communication. Communicative impact is based on primary human emotions: joy, sorrow, fear and anger. The central task of the article is to analyze these aspects and their impact on the human conscience in the information transmitting process. Currently, mass communication media makes full use of the mind manipulation to draw attention to the advertised objects. To study such manipulation, the diverse methods are applied: discourse analysis, semiotic encoding and decoding as well as text analysis. When using these methods, we concluded that modern advertising communication focuses not so much on products and brands, but on the advertising piece. Advertisement videos demonstrate comfort, safety, ease of use of the product, etc. Advertisers pay attention to communicator qualities and the communication situation itself, which presents advanced features of a product. Communicators are most often well-known personalities acting as opinion leaders, so their messages are based on the advertiser confidence effect. The media space can include "seasonal" ads. This type of communication is presented in the form of brand advertising messages on the eve of various holidays or events linking a product with them. Online platforms and applications commercials are getting the significant evolvement in the TV advertising discourse. Online advertising drags TV content consumers into digital communication. Eventually, it should be emphasized that advertisers exert influence on the discourse as well as develop the advertising communication and, consequently, affect the recipients' emotions. Consumers, in turn, guided by emotions, make a choice in favor of a particular product.

Keywords: discourse, advertising, manipulation, communicator, message.

\section{Resumen}

El artículo presenta facetas comunicativas, estilísticas y retóricas del discurso publicitario. El propósito del estudio es considerar los medios comunicativos (retóricos y estilísticos) del discurso publicitario en el papel de prácticas sugerentes que actúan como manipulación de la mente. El objetivo principal de tales medios es vender bienes a través de la comunicación masiva. El impacto comunicativo se basa en las emociones humanas primarias: alegría, tristeza, miedo e ira. La tarea central del artículo es analizar estos aspectos y su impacto en la conciencia humana en el proceso de transmisión de información. Actualmente, los medios de comunicación masiva hacen un uso completo de la manipulación mental para llamar la atención sobre los objetos anunciados. Para estudiar dicha manipulación se aplican los diversos métodos: análisis del discurso, codificación y decodificación semiótica y análisis de texto. Al utilizar estos métodos, llegamos a la conclusión de que la comunicación publicitaria moderna se centra no tanto en productos y marcas, sino en la pieza publicitaria. Los videos publicitarios demuestran comodidad, seguridad, facilidad de uso del producto, etc. Los anunciantes prestan atención a las cualidades del comunicador y la situación de la comunicación en sí, que presenta características avanzadas de un producto. Los comunicadores suelen ser personalidades conocidas que actúan como líderes de opinión, por lo que sus mensajes se basan en el efecto de confianza del anunciante. El espacio de medios puede incluir anuncios "estacionales". Este tipo de comunicación se presenta en forma de mensajes publicitarios de marca en vísperas de diversas festividades o eventos vinculando un producto con ellos. Las plataformas en línea y los comerciales de aplicaciones están experimentando una importante evolución en el discurso de la publicidad televisiva. La publicidad en línea arrastra a los consumidores de contenido de televisión a la comunicación digital. Finalmente, conviene enfatizar que los anunciantes ejercen influencia en el discurso así como desarrollan la comunicación publicitaria y, en consecuencia, afectan las emociones de los destinatarios. Los consumidores, a su vez, guiados por las emociones, hacen una elección a favor de un producto en particular.

Palabras clave: discurso, publicidad, manipulación, comunicador, mensaje. 


\section{Introduction}

Manipulative technologies are actively exploited by modern mass media. The rhetoric research aspect deals with the agonic communication, but the characteristics and classifications of such communication are considered insignificantly in a modern research. The task of any advertising and PR text is to touch upon person's emotions deriving benefit from selling goods, communication influence and generating opinions in the news discourse. "Advertising is an economic and psychological phenomenon. The advertising manipulation comes into action with the involvement of well-known TV presenters. The viewer perceives their calls to buy goods as a personal attitude. This attitude is taken through associations" (Polukarov, 2004, p. 55). The purpose of the study is to view television advertising stories in terms of the recipients' discourse manipulation through rhetoric and stylistic messages. "The advertising uses psychological complex and manipulative tools to outflank the critical evaluation of the cognitive sphere. The time shortage is compensated by expressiveness." (Luman, 2005, p. 73). Thus, there is an expression and a content combination, which is reflected in the creolized text, creating suggestive techniques by means of visual effects and advertising audio support. Such configurations affect the consumer's emotions. Often times, when facing a choice of goods, the consumer instinctively remembers the story and then chooses a certain type of a product (Ivanov, 2019, p. 25). In the study, the author relies on the theory of the power of discourse and power over discourse by $\mathrm{T}$. van Dijck. The analysis of commercials points to the conclusion that the advertising discourse forms suggestive methods of influencing potential recipients via rhetoric and stylistics. "There are three reasons that make trust the speaker, because there are so many things that we believe in without proof, namely, intellect, honesty and benevolence" (Aristotle, 2000, p.112). For example, trust is developed by the involvement of famous personalities in advertising; tenderness is created on the basis of children's images and animals; communication associations are shown by precedent stories related to a certain category of goods in advertising (tea is advertised in Japanese and Chinese surroundings) and reference to the past is presented by the impact on emotions of the older generation (Indian tea with an elephant, Soviet ice cream, sausage recipes of the 1970s).

\section{Theoretical framework}

The communication of modern mass media is aimed at getting some benefit from recipients, which is achieved by manipulating the consumers' minds through various discursive practices. Similar examples can be seen in news, political and advertising discourses. To explore the viewed topic entirely, we will focus on the last one. Mind manipulation origins, namely, argumentation and manner in persuading the interlocutor, go back to antiquity. It is worth viewing the confrontation between Plato and Protagoras. The former referred to the truth of the judgment (akreba and alethea) and the latter relied on the principle of competition (agon) during the communication process. The confrontation between Plato and Protagoras can be considered as a prototype of the modern PR and advertising content. In addition to above-mentioned approaches, there existed the rhetoric of Isocrates (epideictics) and Aristotle (logic) in antiquity (Shatin, 2012, p. 6). In regard to advertising, it should be noted that the logical intercommunication goes back to Aristotle's rhetoric, but the use of tropes traces to Isocrates. Demetrius pointed at speech segments during the communication (colas), which helped stylistically express an opinion (Takho-Godi, 1978, p. 168). The ancient philosopher considered the representation of the thought of a communicator speaking to the public to be the main objective of such segments. The advertising communication regards speech segments as ways to introduce a product to a consumer, to present it as well as to communicatively impact a prospective recipient in order to promote the product. Accordingly, advertising occurs not only as separate blocks in mass media, but it can be also integrated in TV shows, internet blogs (vlogs), TV series, and so on. Internet hosting companies use a similar way to promote diversified products, whose advertising in the media is restricted by the current advertising legislation. The cooking TV show "Smak", released on the " $1{ }^{\text {st }}$ Channel" for 25 years, came to an end, but the team that produced the program moved to youtube hosting, where the show presenter Andrey Makarevich advertises vodka "Talka", offering guests of his program to drink it. 
The modern sense of communication messages is rendered as the power of discourse and power over discourse. We define the discourse as the communication that generates an event. $\mathrm{T}$ Van Dijk mentions the control over discourse. The scientist reports: "If communicative actions are used, namely, the discourse, we are dealing with a more specific type of control, i.e. the control over other people's discourse (Dijk, 2013, p.27). The control over the media discourse is manifested in the advancement of interests of owners of mass communication media. "In this way, the power of discourse indicates the possibility of broad social manipulation, which "channelizes" theories, ideas, assessments, views, judgments and post-communicative actions of various subjects or objects in a special way" (Chernyavskaya, 2006, p.80). The modern media space comprises all communication channels belonging to different holdings. In the mid-90s in Russia, the holdings were owned by influential people and dollar millionaires, but as for modern mass media, a majority stake of many holdings belongs to state-owned companies: "Gazprom media", "First channel" PLC, VGTRK and others. Indeed, modern communication does not advertise a product itself giving preference to emotions. Current communication practices affect the potential consumers' feelings making them feel ashamed, be proud or sorry. A. Ivanov determines the following advertising registers that can persuade a potential consumer to buy a product: guilt, fear, interest in the presented communication in the media, envy, etc. His major concept is to analyze the impact on the consumer's emotions during a product purchase. The author describes the following communication: the situation when a woman comes to the market to buy "Klinskie" sausages. The first seller refuses, explaining his response by the fact that they simply ran out. The seller of the second counter replies in the affirmative and starts looking for sausages, then politely apologizes and offers to buy "Cherkizovsky" sausages similar to their taste and composition. Naturally, the buyer will have a sense of guilt for the fact that the seller was looking for and helped in choosing a product for the consumer (Ivanov, 2019, pp. 37-38). Marketing implements such techniques, for example, in conducting product tastings as well as advertising employs them in a communicator message. Messages, presented on various channels of mass communication, reveal the connotative semantics as one of the three dimensions of semiotics. U. Eco notifies that "Semantics studies not only general lexical meanings, but also related terms, colour codes, religious systems, classical taxonomy and value paradigms" (Eco, 2004, p. 514). From the perspective of these registers, it can be noted that advertising communication has connotations, whose components prevail in an advertising message. "The trend connotation is not autonomous, i.e. the mentioning fact cannot be separated from what is noticed. Therefore, a verbal vestimentary code captures the whole system and, moreover, as for statements, a trend statement coincides with a terminological statement of vestimentary features and acts as a denotation" (Barth, 2003, p.44). According to the advertising communication which forms recipients' opinions, the denotation can serve as images of heroes and their simulated situations. Such advertising images help the brand get recognition and stand out among the advertising communication noise. M. Pecheux reports on the transition from "function to functionality", denoting the integration of "the conceptual framework of literary, mythological and linguistic systems" (Pecheux, 1999, p.307). Consequently, we analyze the advertising message in a combination of rhetoric and stylistics. An advertiser focuses the consumer's attention on the colour and quality transformations of a product, core audience and so on. In the advertising of the project "Searching for pets" by the dog food manufacturer "Purina", the pathos shows regret to other people and help in finding a favorite pet. In this regard, communication offers to sign up the project website. The visual message code conveys the inefficiency of paper ads of such nature. The main character of the ad, a boy of primary school age, passes an adult a paper ad about a missing dog. Suddenly, the wind blew and his message was lost. The dog appears exactly at the moment when the boy puts an ad on the advertised site. When decoding the auditory communication component, the recipient recognizes the Gazmanovs' son and father "Lucy" song, which was dedicated to the missing dog. Advertising does not confer the qualities and advantages of dog food over competitors. Its aim is to touch the consumer's feelings. If you help people find their favorite animals, you can buy dog food advertised by the manufacturer. E. Aronson and E. Pratkanis, referring to Protagoras, notice comparison in the advertising communication. One brand compares itself with another and demonstrates benefits, for example, "McDonalds" and "Burger King", "Pepsi" and "Coca-Cola" (Aronson, Pratkanis, 2003, p. 151). We can also parallel the "Arko" and "Gillette" shaving foams. 
One commercial of" Arko" shaving foam uses the slogan: "It's better for men." The presented communication adverts to a well - known slogan: "Gillette. There is no better for a man".

Analyzing the discourse, we can distinguish a set of communication situations: a delicious dinner with mayonnaise, a family vacation, a journey with a mobile phone that has an HD camera allowing you to take contrasting photos and so on. The timing of modern television advertising is also worth mentioning. Most of videos range from 10 to 50 seconds. This tendency can be characterized by the high TV commercial cost as well as the use of manipulative technology "sideway"specified by E. Aronson and E. Pratkanis. The reference [17] quotes that "People who listen and watch the TV message "by the way" do not simply think about it, do not subject it to critical consideration, but perceive it as a background, literally, as part of a conversation or even an internal dialogue" (Solovey, 2017, p. 116).

\section{Methodology}

The analysis is based on modern Russian television advertising, since it is the most suitable for qualifying as stylistic and rhetorical aspects of mind manipulation of a creolized text. A creolized text is defined as an analysis of semiotic message components: voice-over, music and picture. The advertising material analysis is founded on the following methods: descriptive, content analysis, semiotic, media-linguistic and stylistic analysis. These methods provide the most complete formation of suggestive techniques achieved by advertisers through rhetorical and stylistic advertising communication and further impact on potential recipients.

\section{Results and discussion}

The author classifies mass media commercial messages as the advertising discourse polystylistics. Researcher R. I. Mokshantsev designates advertising situations formed by connotative types as follows: 1) sweet, showing a fairy tale with a happy ending; 2) shock, illustrating thrillers; 3) paradoxical, violating generally accepted genre norms (Mokshantzev, 2003, p.78). With regard to Mokshantsev's thesis, we specify the following polystylistic varieties within the abovementioned advertising types. The sweet stories touch upon moving, compassionate and trusting stylistics. The style of augmented communication concerns the past. The advertising associations mean messages containing a precedent phenomenon or referring to a competitor's ad. The shock situations are of frightening and inflammatory style as well as paradoxical plots contain advertising that does not meet its stated characteristics. In accordance with theoretical and practical research of scientists (E. Arson and Pratkanis report on methods of suggestion and influence on a potential targeted audience, R. Bart declares that mass media and society follow the latest trends, T. van Dijck and V. E. Chernyavskaya tell about the discursive impact on the masses, A. Ivanov notifies that the advertising communication affects emotions), the author comes to the conclusion that these stylistic varieties of connotative types are formed by suggestive methods through presupposition or by influencing the audience with the help of polycode message communication techniques. The message depends on visual effects of the advertising material, timbre, speech rate, communicator's image and audio backup. "The efficiency of the advertising communication with the use of visual signs is conditional on the process of symbolic information decoding by different individuals. The study of the decoding process of symbolic messages is a factual analysis of the visual signs impact on a person" (Pendikova, Rakitina, 2011, p. 277). In turn, Yu. K. Pirogova defines the following criteria for the communicative efficiency of an advertising message: "1. Recognizability (identifiability) of an advertising message; 2. Memorability; 3. Attractiveness of a message; 4. Propaganda of a message" (Pirogova, Parshin, 2000, p. 227). Undoubtedly, a decoding content is one of the important factors in advertising. G. G. Pocheptsov reported: "The decoding process involves advertising signs identification, determination of social myths associated with these signs via connotations as well as transition from mythical values to an advertised product and results in searching for the correspondence of the mythical meaning and understanding of our world beyond advertising" (Pocheptsov, 2001, p. 245). 
The fact of the matter is that most consumers of TV content, including a TV set, take "their" minds of the routine. Initially, ad blocks gained attention with sound contrast (the sound of an ad block became much louder than the sound of a TV show). Nowadays, as we noted, a big role in attracting the audience's attention to the telescreen and its information impact is played by communication situations shown in advertising. "Immersiveness is one of the most important components of an ad impression. For example, TV viewers who recall some personal situations from real life while watching a program are highly engaged ones" (Bryant, and Thompson, 2004, p. 314). Online service "Apteka.ru", draws the attention of its potential consumers by using the cartoon characters "Masha and the Bear" in advertising communication. The video lasts 10 seconds, during the ad, the recipient exclusively focuses on the cartoon characters who order medicines online. The emphasis on cartoon characters was made intentionally to extract advertising from the "communication noise" appeared in a variety of other advertising messages. The term "communication noise" is denoted in continuation of the definition of the ShannonWeaver communication model, the main idea of which was to isolate communication from the information flow. The model "is the basis of the information-coded communication model that concerns the following: both, a speaker (sender) and a listener (recipient) have language encoding or decoding devices and procedure for processing and keeping the thought and information" (Vysotskaya, 2017, p.6). Animated series characters feature such advertising, because they garner attention as recognizable communicators in the discourse process. The "Pandora" jewelry store commercial places the emphasis on the image of the main character in a fictional world where the girl says: "I like to dream". The advertising visuals are accompanied by pink tones. Despite the focus on the heroine, a new jewelry collection is mentioned in the video at second 9 out of 14 . The purpose of this commercial is to show her dreaminess expressed in the jewelry of the "Pandora" new collection. Through the visual and auditory series, the advertiser tries to interact in the following way: each girl who is a potential targeted audience of this commercial could be dreamy and go with the heroine communication image.

Tea "Saito" creates its advertising communication on the atmosphere of Asia. The commercial audio sequence is accompanied by characteristic melodies resembling Chinese or Japanese national music. It is said in the commercial: "Try the magic of Asia with every cup of Saito tea". The commercial entourage is visually demonstrated by a woman in the national Chinese costume as well as by the process of brewing tea pictured in close-up. In a similar manner, an advertiser focuses on the brand's associations with tea traditions of the East pointing out the sophistication and quality of the advertised product.

On the eve of various holidays and major sporting events, advertisers create communication messages in an appropriate style. Such commercials are shown on New Year's Eve, May holidays, world cups in football and hockey and so on. The communicators in these videos are the "prominent figures" of TV channels that broadcast such commercials. TNT TV channel advertises coffee "Nescafe Gold" with Marina Kravets. According to the video plot, the heroine, acting as a communicator, comes to friends for a festive evening with a coffee can. The visual code of this message betrays the holiday atmosphere with the New Year's dinner table, at which the video characters celebrate and drink coffee. The commercial with TV presenter Regina Todorenko, advertising the shop "Svyaznoy", is also made in a style of a festive atmosphere. Analyzing the message audio code, it should be noted that during the communication process, the attention is paid not only to the mobile phone shop, but specifically to the brand of the smartphone "Honor $20 \mathrm{S"}$ " The TV presenter takes a selfie, while the off-screen voice is explaining the advantages of the mobile phone camera.

Looking at the visual content of the video, we can see a sleigh with harnessed reindeer wrapped in a garland, which the communicative consciousness associates with the Santa Claus team and then with New Year's holidays.

In spring and autumn, a large number of videos of remedies for colds, ARVI, and allergies are shown. Relatively soon, there will be an advertising competition for manufacturers of vaccines 
and drugs against the coronavirus infection that possessed the world in 2020. Before the New Year and May holidays commercials promote medicines and dietary supplements that help restore bowel activity, flush out toxins after poisoning, etc. Such messages present communicators who act out a family feast or take care of children who have a cold. The commercial of "Coldrex. Menthol" demonstrates the scene with the mother who has a cold, and therefore the family members cannot cope with the kitchen chores. Under such circumstances, "Coldrex" can quickly cure and cope with a cold. A notable advertising communication is the advertisement of the mobile phone "Iphone 11", where a ccommunicator is an advertised object itself. The communication provides a focal point at the phone durability and strength under the impact of various objects and all advertising communication is accompanied by music. The advertising communicators of cocoa for children "Nesquik" are children who address their parents. The following is said in the ad: "Moms and dads, being a parent means keeping a balance between what we want and what we need". The communication goes on mentioning that cocoa contains $30 \%$ less sugar than the original version. Firstly, the visual imagery depicts children, then school textbooks on a tray that are associated in the minds of communication participants with the balance between study and rest in the form of vitamins received by children when drinking cocoa. The slogan of the advertised product is: "Balance of taste and benefit", which emphasizes the taste and usefulness of the product, despite the fact that it contains less sugar. Leonid Yakubovich acts as an advertising communicator of tea "Azerchay". A well-known TV presenter appears as an old man Hottabych on a magic carpet. The video lasts 18 seconds, so the advertiser focuses on an unusual image of the TV presenter who creates the advertising communication.

Each above-mentioned video wields major influence on recipients through a communicator who conveys the advertiser's encoded advertising message. During the submitted messages decoding, the targeted audience directs attention not only to the product, but additionally to the communicator in character of cartoon heroes, a dreamy girl or an Eastern woman who knows a lot about the tea ceremony, an old man Hottabych, etc. Consequently, the potential audience gets under the influence of communication via associations, considering not only the product quality, but also advertising discursiveness in general.

Modern advertising communication demonstrates the dynamics in the change of characters' images, quick storyboarding and clear audio message accentuation. These parameters correspond to the advertising of online application "Yula", whose visual code comes out in dynamic dances and stylistic changes of characters who buy sneakers, running equipment and clothes. The advertising audio codeis represented by the following theses: buy fast, get cheap and change. Actually, such online platforms as "Yula" or "Avito" replaced printed publications with informatory and meaningful text advertisements. Such advertising does not appeal to buy a product, but it just involves us in communication, offering to change the image, be fashionable and purch a sethings cheaper than in a shop.

\section{Conclusion}

To sum up, it is important to note that recent television commercial communication conforms to radio advertising. We made such conclusion by analyzing the following characteristics: timing, creation of communication situations and recogniz a blueback ground music. Both radio and TV advertising focuses on the characters representation as well as the communication situation. In such instance, the advertiser's main task is to associate the brand with any phenomena, images or characters. The communicative positioning of the product and its marketing component come to the fore in communication. Accordingly, the given examples show that the cleaning product "Comet" is associated with the victory over dangerous bacteria, tea with traditions of the East, online platforms with fast purchase and money savings, etc. Indeed, at the beginning of the XX century, radio advertising was the leading communication for product promotion, and then TV commercials possessed the priority. Nowadays, the similar tendency is observed in transferring an advertising content to Internet space. Television advertising discourse stands out against the TV discourse background. TV entertainment programs show us "celebrities of the past", for 
instance, guests from the Soviet TV show "Kabachok 13 chairs" in one of talk shows on "Channel 1", which impresses the targeted audience and is characterized by V. D. Solovey, as "the principle of age curtsey" (Solovey, 2017, p. 215). Naturally, the person who has power over the discourse (T. van Dijk's term) makes the corresponding communicatory notification. Similar mechanisms are implemented in advertising and entitling a great number of products and foodstuff, namely, ice cream "SSSR" and"as formerly" sausage from a well-known Novosibirsk Region manufacturer "Torgovaya ploshchad" as well as Indian tea with an elephant on the packet was earlier positioned as "the same tea". The point is that advertising of such nature correlates with the communicatory notification in general. E. Podshivalova reports about the "peculiar" taste of a Soviet ice cream. The ice-cream company "Inmarko" carried out the research and fund out the following secret:"Soviet ice cream had a special taste, because it burned to the walls of old pasteurizers", but more modern equipment could not obviously provide"the taste of childhood" (Podshivalova, 2012). Furthermore, when TV shows space engineering achievements ofthe late 1950s and early 1960s, "the very same" sausage or tea appears in stores. In the mid-90's, when the media discourse presented democratic values, supporting communication with prerevolutionary examples, such a trade brand as "Dovgan", producing a huge number of consumer goods, advertised the pre-revolutionary brand history of products made in those days and emerged plenty of years later. Consequently, the essence lies in the collective consciousness.

Conventionally, an advertiser adapts to an appropriate mind theory formed by the power over the discourse and introduced to the general population. Meanwhile, the online services advertising shows young and energetic people as communicators for promoting advertised products. Generally, the point is that such communication, inversely to above-mentioned examples, is aimed at a younger audience that uses mobile applications rather than Internet sites and can buy a product offered on the website in a few clicks. Further consideration of this problem will allow forming the connotative varieties of stylistic types formed by suggestive techniques in a polycode message in relation to mass communication media: $\mathrm{TV}$, radio, printed press and Internet publications.

\section{Acknowledgment}

The author thanks Shatin Yuri, doctor of Philological Sciences, Professor of the Department of history and theory of journalism of Novosibirsk State University, for the long - term contribution to the scientific development of articles and research papers.

\section{References}

Aristotle, (2000). Rhetoric. Poetics. Aristotle, translated from ancient Greek. by O. Tsybenko. Moscow: Labyrinth.

Aronson, E., Pratkanis, E. (2003). The era of propaganda: mechanisms of persuasion, everyday use and application. SPb: Praim-evroznak.

Bart, R. (2003). The fashion system. Moscow: Sabashnikovih Publishing House.

Bryant, D., Thompson,S.(2004). Fundamentals of media impact. Moscow: ID Vilyame

Chernyavskaya, V. E. (2006). Discourse of power and power of discourse: Problems of speech influence. Moscow: Flinta

Dijk, T. van. (2013). Discourse and power: Representation of dominance in language and communication. Moscow: URSS

Eco, U. (2004). Missing structure. Saint Petersburg: Symposium 
Ivanov, A. (2019). Advertising: Playing on emotions. Moscow: Alpina publisher

Luman, N. (2005). Reality of mass media. Moskow: Paracsis

Mokshantzev R. I. (2003). Psychology of advertising. Moskow: Sibirskoe soglasheniye.

Pecheux, M. (1999). Content analysis and theory of discourse. Quadrature of meaning: The French school of discourse analysis. Moscow: Progress.

Pendikova, I. G., Rakitina, L. S. (2011). Archetype and symbol in advertising. Moscow: Unity

Pirogova, Yu. K., Parshin, P. B. (2000). Advertising text: Semiotics and linguistics. Moscow: International advertising institute publishing.

Pocheptsov, G. G. (2001). Theory of communication. Kiev: Vakler

Podshivalova, E. (2012). Soviet brands in modern culture. [Electronic resource]. https:// culture.wikireading.ru/22634

Polukarov, V. L. (2004). TV and radio broadcasting advertising. Moscow: Dashkov\& Co.

Shatin, Yu. V. (2012). Neo-Rhetoric. Novosibirsk: Novosibirsk state university.

Solovey, V. D. (2017). Absolute weapon. Fundamentals of psychological warfare and media manipulation. Moscow: Eksmo.

Takho-Godi, A. A. (1978). Antique rhetoric. Moscow: Moscow university.

Vysotskaya, I. V. (2017). Communication fails in advertising. Novosibirsk: Novosibirsk state university. 